\title{
Transmissibility of Cucumber mosaic virus by Aphis gossypii Correlates with Viral Accumulation and Is Affected by the Presence of Its Satellite RNA
}

\author{
Fernando Escriu, Keith L. Perry, and Fernando García-Arenal
}

First and third authors: Depto. de Biotecnología, E.T.S.I. Agrónomos, Universidad Politécnica de Madrid, 28040 Madrid, Spain; and second author: Department of Botany and Plant Pathology, Purdue University, 1155 Lilly Hall, West Lafayette, IN 47907.

Accepted for publication 27 June 2000.

\begin{abstract}
Escriu, F., Perry, K. L., and García-Arenal, F. 2000. Transmissibility of Cucumber mosaic virus by Aphis gossypii correlates with viral accumulation and is affected by the presence of its satellite RNA. Phytopathology 90:1068-1072.

Satellite RNAs (satRNAs) are associated with Cucumber mosaic virus (CMV) in tomato, most often causing severe epidemics of necrotic plants, and not associated with specific host symptoms. Laboratory studies on virus transmission by the aphid vector Aphis gossypii were performed to better understand the dynamics of field populations of CMV. The presence of satRNAs correlated with lower concentrations of virus in infected plants and with a decrease in the efficiency of transmission from satRNA-infected plants. Both the concentration of virus in CMV-

infected tomato and the efficiency of transmission varied more extensively with nonnecrogenic satRNAs than with necrogenic satRNAs. A negative effect of satRNAs on virus accumulation can account, in part, for a decrease in the field transmission and recovery of CMV + satRNAs. Aphids behaved differently and probed less readily on plants infected with CMV + necrogenic satRNAs compared with plants containing nonnecrogenic satRNAs. Aphid-mediated satRNA-free CMV infections were observed in test plants when aphids were fed on source plants containing CMV + nonnecrogenic satRNA; no comparable satRNA-free test plants occurred when aphids were fed on source plants containing necrogenic satRNAs. These results indicate that factors associated with transmission can be a determinant in the evolution of natural populations of CMV and its satRNA.
\end{abstract}

Transmission by arthropod vectors is a strategy that many plant viruses have developed to colonize new hosts and spread in the environment. Nonpersistent transmission by aphids is the most common transmission strategy for plant viruses and may have an important effect on the dynamics and evolution of virus populations. Because viruses usually are differentially transmitted by species or biotypes of vectors $(3,25,34,36)$, vector transmission would result in the selection of virus populations adapted to changes in vector populations. Also, because a small quantity of virus suffices to initiate the infection of a new host (39), transmission events could represent genetic bottlenecks and thereby introduce random elements in the evolution of the genetic structure of virus populations (36).

Cucumber mosaic virus (CMV) is a plant virus with a genome composed of three single-stranded, positive-sense, RNA segments, each of which is separately encapsidated in isometric particles. CMV has a very broad host range and is efficiently transmitted in a nonpersistent manner by many species of aphids (reviews of CMV in Palukaitis and García-Arenal [31] and Palukaitis et al. [32]). Aphis gossypii is an efficient vector of CMV in experimental conditions and in the field $(21,41)$. The primary determinant of aphid transmissibility for CMV is the coat protein $(\mathrm{CP})(6,11)$. Specificity and efficiency of transmission of CMV strains by species of aphids has been mapped to several domains in the amino acid sequence of the CP $(34,35,40)$. These domains could be directly involved in the binding of virus particles to aphid receptors or, alternatively, affect the stability of particles in the aphid stylet and foregut (34). CMV associates with a small, single-stranded satellite RNA (CMV-satRNA) that modu-

Corresponding author: F. García-Arenal; E-mail address: fga@bit.etsia.upm.es

Publication no. P-2000-0727-01R

(C) 2000 The American Phytopathological Society lates the accumulation and pathogenicity of CMV in a way that depends on the strains of CMV and satRNA and on the species of host plant (reviews in García-Arenal and Palukaitis [10]). CMVsatRNA requires CMV as a helper virus (HV) for its replication and encapsidation into CMV particles, through which it can be transmitted with the viral genomic RNAs (15). Details of the encapsidation and transmission of CMV-satRNA are not clear. It is not known whether satRNA is encapsidated with CMV genomic RNAs or separately in different CMV particles (23). Thus, it is not known whether it is the distribution of the satRNA in CMV particles or the interaction between CMV and satRNA that affects aphid transmissibility of CMV and its satRNA.

We have analyzed the transmissibility of CMV-satRNA variants and their effect on the transmissibility of CMV by A. gossypii. Here we report that transmission of CMV correlates positively with the accumulation of virus particles in source plant tissues and that the presence of CMV-satRNA reduces the efficiency of transmission. These results are relevant for understanding the genetic structure and dynamics of populations of CMV and CMVsatRNA and may be determinant for their evolution in epidemics.

\section{MATERIALS AND METHODS}

CMV and CMV-satRNA isolates. CMV-satRNA isolates were obtained from field-infected tomato plants sampled between 1989 and 1994. Tomato plants were grown in Eastern Spain and were affected by an epidemic of tomato necrosis caused by CMV + satRNA (17). CMV-satRNA variants were named $N / i j$, meaning satRNA variant $j$ from CMV isolate $i$ obtained in year $N$ (2). Five variants necrogenic for tomato $(89 / 15.1,89 / 42.1,90 / 22.1,91 / 5.1$, and $94 / 32.1)$ and six variants nonnecrogenic for tomato $(89 / 15.2$, 89/20.1, 90/14.1, 90/17.1, 90/19.2, and 91/2.2), described in Escriu et al. (8), were used. Fny-CMV, derived from infectious RNA transcripts from full-length cDNA clones (42), was propa- 
gated in tobacco plants (Nicotiana tabacum cv. Xanthi-nc). CMVsatRNA variants were also multiplied in cv. Xanthi-nc tobacco plants from RNA transcripts obtained from full-length cDNA clones (8) with Fny-CMV as HV. CMV particles were purified from infected tissues according to Lot et al. (24), and virion-RNA was extracted by disruption with phenol and sodium dodecyl sulfate (SDS) (33).

Aphid transmission experiments. Fny-CMV RNA, with or without CMV-satRNA, was used to inoculate cotyledons of tomato plants (Lycopersicon esculentum cv. Rutgers) at $10 \mu \mathrm{g} / \mathrm{ml}$ in $0.5 \mathrm{mM}$ EDTA ( $\mathrm{pH}$ 8.0). Plants were inoculated at the two-leaf stage to avoid rapid development of necrosis in plants inoculated with satRNA variants necrogenic for tomato; a rapid onset of necrosis would result in leaves inappropriate for aphid feeding. Infected plants were used as virus sources for transmission experiments at 14 to 27 days postinoculation. A. gossypii maintained at Purdue University were reared on cucumber (Cucumis sativus). Before acquisition, aphids were collected and stored at $4^{\circ} \mathrm{C}$ for 3 to 6 days and then fed on systemically infected leaves of source plants. Only apterous aphids were used. $\mathrm{Cv}$. Rutgers tomato seedlings were used as test plants 9 to 13 days after sowing. Three aphids were monitored for feeding behavior for 1 to $5 \mathrm{~min}$ and were transferred to fully expanded cotyledons of each test plant. In all experiments, $\approx 48$ plants were employed for each of the three treatments (Fny-CMV alone or Fny-CMV with necrogenic or nonnecrogenic satellite). The time taken for aphids to begin feeding was estimated by measuring the time required to complete a treatment, e.g., to probe and transfer 144 aphids to 48 test plants. Transmission experiments were conducted so the three treatments were performed together on the same day, but not always in the same sequence. Aphids were held on test plants for 12 to $24 \mathrm{~h}$ and then were sprayed with acetate (Orthene, Valent Corp., Germantown, TN). Test plants were scored for symptoms of CMV infection and for satRNA-induced necrosis 15 and 30 days after aphid inoculation.

Quantification of CMV particles and analysis of CMVsatRNA infection. After the completion of transmission experiments, virus particles were purified from whole source leaves as described by Lot et al. (24), except only one cycle of differential centrifugation at $8,000 \times g$ for $10 \mathrm{~min}$ and $337,000 \times g$ for $30 \mathrm{~min}$ was made. Virion pellets were resuspended in $500 \mu \mathrm{l}$ of $50 \mathrm{mM}$ sodium borate and $0.5 \mathrm{mM}$ EDTA $(\mathrm{pH} 9.0)$ per gram of tissue (fresh weight). CMV CP was quantified in $100 \mu$ l dilutions of $1 / 10,1 / 100$, and $1 / 1,000$ of these viral preparations by doubleantibody sandwich-enzyme-linked immunosorbent assay (DASELISA) (7). Known amounts of a single preparation of Fny-CMV particles ( $3.16 \mu \mathrm{g}$ to $31.6 \mathrm{ng}$ in a series of 1.78 -fold dilutions) were included as internal standards in every experiment. The antibody raised against Fny-CMV and the DAS-ELISA were done as described previously (33).

CMV and necrogenic satRNA infection of test plants was detected by visual observation of mosaic, stunting, and fern-leaf symptoms typical of Fny-CMV or by unequivocal symptoms of necrosis. Nonnecrogenic satRNA infection was analyzed by dotblot hybridization of total nucleic acid extracts (27) of systemically infected tomato leaves. Hybridization was done overnight at $65^{\circ} \mathrm{C}$ in $6 \times \mathrm{SSC}(1 \times \mathrm{SSC}$ is $0.15 \mathrm{M}$ sodium chloride plus $0.015 \mathrm{M}$ sodium citrate at $\mathrm{pH} 7.0$ ), $5 \times$ Denhardt's mix, 0.1\% SDS, and $250 \mu \mathrm{g} / \mathrm{ml}$ of yeast tRNA (44) with a ${ }^{32} \mathrm{P}$-labeled cRNA probe derived from a full-length clone of B2-satRNA (5).

Estimation of transmission frequencies and statistical analyses. To make valid comparisons of CMV transmission efficiencies, an estimate of the probability of virus transmission by a single aphid was derived from the expression $F=1-(1-R / N)^{1 / \mathrm{i}}$ (12), where $F$ is the estimated frequency of transmission by one aphid, $R$ is the number of infected test plants, $N$ is the number of total test plants, and $i$ is the number of aphids per test plant used for transmissions.
Transmission frequencies were compared by a $G$ test or by a Fisher's exact test (pages 745 and 738, respectively, in literature citation 46) for analysis of independence in contingency tables. Data of CMV viral accumulation levels were analyzed by a Bonferroni test in orthogonal comparisons of means (pages 233 and 530 in literature citation 46). Correlation between the frequency of transmission by a single aphid and viral accumulation in source leaves was analyzed by correlation analysis (page 561 in literature citation 46) after double-logarithmic or logarithmic transformation of the data for linearity.

\section{RESULTS}

The presence of CMV-satRNA results in reduced transmissibility of CMV. Transmission experiments with $A$. gossypii as a vector were designed to analyze whether the presence of CMV-satRNA had any effect on the transmissibility of CMV, to test whether the effects were the same for satRNA variants necrogenic and nonnecrogenic for tomato, and to compare the transmissibility of these two variants. For this, tomato plants inoculated with Fny-CMV or Fny-CMV plus each of five satRNA variants necrogenic for tomato or six satRNA variants nonnecrogenic for tomato, were used as virus sources. Transmissions involved three trials for each CMV/satRNA combination and nine trials for CMV without satRNA. In all cases, transmissions were done with three aphids per test plant. Results shown in Table 1 indicate that the presence of satRNA variants caused a significant depression $(\mathrm{P}<0.0001)$ of the transmissibility of CMV by $A$. gossypii, and that this effect was similar when pooled data for all necrogenic and for all nonnecrogenic satRNA variants were compared (reduction of 24 and $28 \%$, respectively, assuming a $100 \%$ frequency of transmission for Fny-CMV). However, CMV transmissibility in the presence of nonnecrogenic satRNA variants varied greatly for each variant, ranging from 35 to $81 \%$. This was not the case for necrogenic satRNA variants for which CMV transmissibility was 64 to $66 \%$.

Table 1 also indicates the fraction of CMV-infected test plants infected with satRNAs. Although infection by necrogenic satRNA variants was in all cases $100 \%$, infection by nonnecrogenic satRNAs varied from 96 to $100 \%$ (98\% on average). This difference, although small, was significant according to Fisher's exact test for independence $(P=0.0076)$. Thus, necrogenic satRNA variants showed a slightly higher probability of being aphid-

TABLE 1. Transmissibility of Cucumber mosaic virus (CMV) with and without satellite RNA (satRNA) variants by Aphis gossypii in tomato plants ${ }^{\mathrm{y}}$

\begin{tabular}{lcc}
\hline Fny + satRNA variants & CMV $^{z}$ & satRNA \\
\hline No satRNA & $369 / 429(86)$ & $\ldots$ \\
Necrogenic & & $91 / 91(100)$ \\
$89 / 15.1$ & $91 / 140(65)$ & $62 / 62(100)$ \\
$89 / 42.1$ & $62 / 95(65)$ & $90 / 90(100)$ \\
$90 / 22.1$ & $90 / 136(66)$ & $91 / 91(100)$ \\
$91 / 5.1$ & $91 / 142(64)$ & $93 / 93(100)$ \\
$94 / 32.1$ & $93 / 144(65)$ & $427 / 427(100)$ \\
Total & $427 / 657(65)$ & \\
Nonnecrogenic & & $65 / 68(96)$ \\
$89 / 15.2$ & $68 / 95(72)$ & $114 / 114(100)$ \\
$89 / 20.1$ & $114 / 140(81)$ & $79 / 80(99)$ \\
$90 / 14.1$ & $80 / 144(56)$ & $63 / 65(97)$ \\
$90 / 17.1$ & $65 / 94(69)$ & $76 / 77(99)$ \\
$90 / 19.2$ & $77 / 143(54)$ & $32 / 33(97)$ \\
$91 / 2.2$ & $33 / 93(35)$ & $429 / 437(98)$ \\
Total & $437 / 709(62)$ & \\
\hline
\end{tabular}

y Number of CMV-infected plants over the total inoculated test plants and the number of CMV + satRNA-infected plants over the total CMV-infected plants. Data in parentheses indicate corresponding percentage. Data represent a compilation of nine trials for Fny-satRNA and no satRNA and three trials for all other treatments.

${ }^{\mathrm{z}}$ Transmissions were performed with three aphids per plant. 
transmitted with Fny-CMV than nonnecrogenic satRNA variants. During transmission experiments, aphids took about twice as long to probe leaves of tomato plants infected with Fny-CMV + satRNA variants necrogenic for tomato $(55.80 \pm 6.89 \mathrm{~s}$, data from five experiments involving 144 aphids each) as it did to probe leaves of plants infected with Fny-CMV alone or plus satRNA variants nonnecrogenic for tomato $(26.75 \pm 0.63 \mathrm{~s}$ and $28.33 \pm 0.67 \mathrm{~s}$, respectively, data from four and six experiments involving 144 aphids each). These results were in spite of the fact that source leaves did not show evidence of necrosis.

Relationship between CMV transmissibility and viral accumulation in source leaves. The CMV-satRNA-associated reduction of CMV transmissibility shown in Table 1 could be mediated by a satRNA-induced depression in the accumulation of CMV or other effects directly affecting the mechanism of transmission (i.e., altering the virus particle structure). The presence of satRNA could result in a reduction of the accumulation of CMV depending on the isolate of CMV and the variant of satRNA $(18,47)$. CMV accumulation in source leaves was estimated by a quantitative ELISA of virions purified from source-leaf tissues after each transmission experiment. The probability of CMV transmission by a single aphid was estimated according to the equation of Gibbs and Gower (12) and was represented as a function of the accumulation of CMV particles in source leaves. Table 2 shows that the presence of CMV-satRNA resulted in a significant depression in Fny-CMV accumulation $(P<0.0001$, Bonferroni test for comparisons of means on an analysis of variance [ANOVA] involving the entire data set). The depression in CMV accumulation was not significantly different for necrogenic and nonnecrogenic satRNAs when analyzed by ANOVA, and different tests for comparison of means, (Bonferroni test $[P=0.885]$, or Fisher's least significant difference test $[P=0.295]$ ), but values for nonnecrogenic satRNA variants showed a larger dispersion than values for necrogenic satRNA variants. Nevertheless, when comparisons were done between only the treatments involving necrogenic satRNAs and those involving nonnecrogenic satRNAs, a low significant difference was found $(P=0.029)$. In some cases, the value of CMV accumulation in the presence of a specific satRNA varied considerably in the three replicate trials (e.g., for 91/2.2; Table 2). The frequency of CMV transmission by a single aphid appeared to correlate with CMV accumulation (Table 2), and this point was analyzed further. Figure 1 represents the

TABLE 2. Accumulation of Cucumber mosaic virus (CMV) particles in source tomato leaves and estimated frequency of transmission by a single aphid

\begin{tabular}{lcc}
\hline Fny + satRNA variants $^{\mathrm{x}}$ & Accumulation $^{\mathrm{y}}$ & Frequency $^{\mathrm{z}}$ \\
\hline No satRNA & $1,343 \pm 163$ & 0.48 \\
Necrogenic & $356 \pm 19$ & 0.30 \\
$89 / 15.1$ & $297 \pm 4$ & 0.30 \\
$89 / 42.1$ & $370 \pm 37$ & 0.30 \\
$90 / 22.1$ & $258 \pm 25$ & 0.29 \\
$91 / 5.1$ & $237 \pm 25$ & 0.29 \\
$94 / 32.1$ & $304 \pm 18$ & 0.30 \\
Total & & \\
Nonnecrogenic & $212 \pm 156$ & 0.34 \\
$89 / 15.2$ & $328 \pm 35$ & 0.43 \\
$89 / 20.1$ & $163 \pm 48$ & 0.24 \\
$90 / 14.1$ & $218 \pm 113$ & 0.32 \\
$90 / 17.1$ & $165 \pm 38$ & 0.23 \\
$90 / 19.2$ & $129 \pm 126$ & 0.14 \\
$91 / 2.2$ & $206 \pm 31$ & 0.27 \\
Total & & \\
\hline
\end{tabular}

x SatRNA = satellite RNA.

y CMV viral accumulation in source leaves (mean \pm standard error), expressed as micrograms of virion particles per gram of fresh weigh.

${ }^{\mathrm{z}}$ Frequency of transmission by a single aphid estimated by the expression of Gibbs and Gower (12): $F=1-(1-R / N)^{1 / 1}$, where $F$ is the estimated frequency of transmission, $R$ is number of CMV-infected test plants, $N$ is the number of test plants, and $i$ is the number of aphids per test plant. relationship between the frequency of transmission by a single aphid and viral accumulation of CMV for each of the assayed source plants. The correlation between both variables was analyzed. To compute the correlation coefficients and their significance, logarithmic transformations of data for CMV accumulation or for CMV accumulation and the probability of transmission were done (Table 3). For both transformations, a significant correlation was found between the variables when data from all source plants were considered. A significant correlation was also found in data from sources infected with only CMV + satRNA but not in data from source plants infected with CMV alone when analyzed separately. This indicates that the efficiency of transmission of CMV depends on the accumulation of the virus in plants, and that the reduction in aphid transmissibility of CMV associated with the presence of satRNAs might be explained by the depression effect of satRNA on the accumulation of CMV. Because values of CMV accumulation with and without satRNA did not overlap, we were unable to determine if other factors associated with CMV-satRNA were involved in the satRNAassociated depression of CMV transmissibility.

\section{DISCUSSION}

CMV-satRNA is a molecular parasite that modulates the accumulation and pathogenesis of its HV CMV (32). CMV-satRNA is aphid transmitted with CMV. The limited work on the possible effect of CMV-satRNA on the transmissibility of CMV suggests that the presence of a satRNA variant could reduce the efficiency of CMV transmission (15). If this were a general effect, it could explain the infrequent occurrence of CMV-satRNA in field isolates of CMV and be an important factor in understanding the evolution of natural populations of CMV-satRNAs, including the evolution of their virulence (8). The data in Table 1 indicate that the presence of satRNA resulted in an important depression in the transmissibility of CMV. These results are consistent with those of Jacquemond (15), who showed that the rate of transmission from plants inoculated with a mix of RNAs of a CMV isolate and a CMV-satRNA isolate was mainly dependent on the species of the

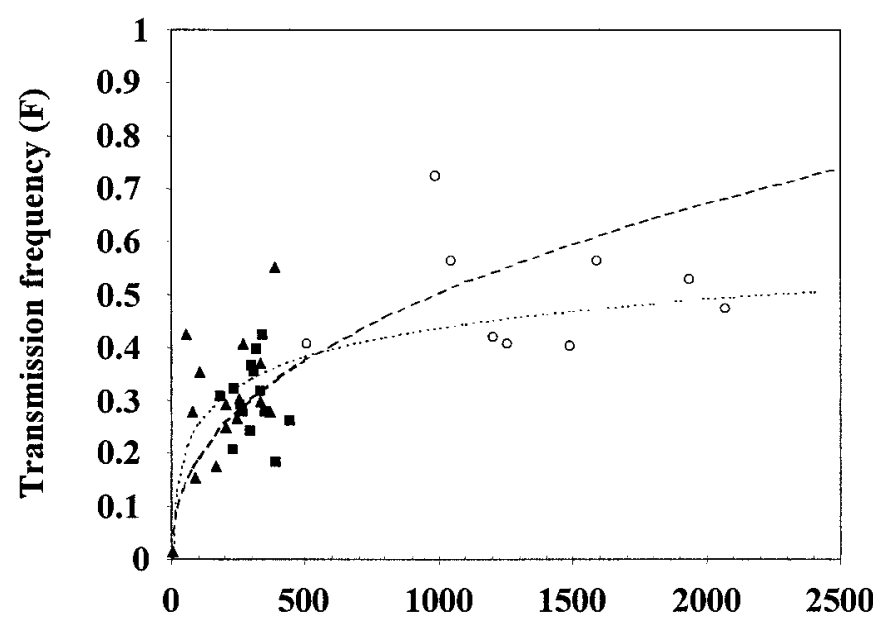

Accumulation of CMV particles (V)

Fig. 1. Relationship between transmission frequency and Cucumber mosaic virus (CMV) accumulation. Frequency of transmission by a single aphid $(F)$ is represented versus accumulation of CMV particles $(V$, micrograms of virions per gram of fresh weight), for source plants infected with Fny-CMV (O), Fny-CMV + necrogenic satellite RNA (satRNA -) and Fny-CMV + nonnecrogenic satRNA $(\boldsymbol{\Delta})$. The result of a regression analysis for pooled data through the logarithmic transformation of CMV accumulation: $F=a+b \times \ln V$ (dotted line), and for transmission frequency and CMV accumulation: $F=a \times V^{\mathrm{b}}$ (dashed line) is shown. Regression parameters and the probability of significance for correlations are indicated in Table 3. 
host plant; a better host for satRNA replication was a less efficient virus source for aphids. Our data also indicate that the satRNAassociated reduction of CMV transmissibility occurs to different degrees among the 11 assayed CMV-satRNA variants, without correspondence between the degree of transmission depression and the pathogenicity of the assayed satRNA variant (necrogenic or nonnecrogenic for tomato).

Data presented in Table 2 show that the presence of the assayed satRNA variants resulted in a significant reduction (up to 10-fold) in CMV accumulation, as reported previously $(13,16,19,28,47)$. It could be that the presence of the satRNA resulted in a lower yield of purified CMV particles during isolation rather than in a depression in particle accumulation in leaves. This is unlikely, because additional data (data not shown) on the concentration of CP antigen in crude extracts of source leaves showed a very good correlation with data on the concentration of purified particles from these same leaves (Table 2). Our data also show that there was a significant correlation between transmissibility by A. gossypii of CMV from tomato leaves infected by CMV + satRNA and virus accumulation in source leaves. Thus, the depression of CMV transmissibility associated with the presence of CMV-satRNA could be explained in part by the negative effect of the satRNA on CMV accumulation. A correlation between transmissibility and virus titer has been shown for nonpersistent viruses in experiments involving acquisition from virus suspensions through membranes (38). Data from experiments in which the virus was acquired from plant tissues are less clear-cut (37). A relationship between in planta virus titer and efficiency of transmission by Myzus persicae and $A$. gossypii has been reported for CMV $(4,29,45)$. In all instances, virus accumulation was reported as data from local lesion assays or as direct ELISA readings with no further attempt at quantification, making these results difficult to compare with our own. Different results were reported by Norman and Pirone (29) and by Gera et al. (11), who found that for some CMV isolates, transmissibility correlated with virus titer when aphids acquired the virus from a suspension but not when the virus was acquired from plant tissues. A relationship between transmissibility and virus accumulation has been reported only at low virus concentrations and quickly reach a plateau $(4,29,45)$. Our results clearly show a correlation between virus accumulation and transmissibility with a possible plateau at virus concentrations higher than $500 \mu \mathrm{g} / \mathrm{g}$ of leaf (fresh weight). In fact, when data taken only from source plants infected with CMV were considered, no correlation between transmissibility and virus accumulation was found. The apparent discrepancies between our results and those of others could be explained by virus concentrations at which transmissibility reaches a plateau; this could vary with CMV strain, host plant, and aphid species. On the other hand, because transmission and virus accumulation do not overlap in our data set for assays involving CMV + satRNA or CMV alone, we

TABLE 3. Correlation analysis between frequency of transmission and accumulation of Cucumber mosaic virus (CMV)

\begin{tabular}{llrrrr}
\hline & & & & \multicolumn{2}{c}{ Parameters } \\
\cline { 5 - 6 } Correlation $^{\mathrm{w}}$ & Transformation $^{\mathrm{x}}$ & $\mathrm{CC}^{\mathrm{y}}$ & \multicolumn{1}{c}{$P^{\mathrm{z}}$} & \multicolumn{1}{c}{$a$} & \multicolumn{1}{c}{$b$} \\
\hline Fny, no satRNA & $F=a+b \times \ln V$ & 0.0530 & 0.8922 & 0.4034 & 0.0134 \\
& $F=a \times V^{\mathrm{b}}$ & 0.1017 & 0.7945 & 0.3462 & 0.0486 \\
Fny + satRNA & $F=a+b \times \ln V$ & 0.5163 & 0.0041 & 0.0102 & 0.0541 \\
& $F=a \times V^{\mathrm{b}}$ & 0.7945 & $<0.0001$ & 0.0170 & 0.5181 \\
Pooled data & $F=a+b \times \ln V$ & 0.6874 & $<0.0001$ & -0.0874 & 0.0788 \\
& $F=a \times V^{\mathrm{b}}$ & 0.7994 & $<0.0001$ & 0.0276 & 0.4203 \\
\hline
\end{tabular}

\footnotetext{
${ }^{\mathrm{w}}$ SatRNA $=$ satellite RNA.

${ }^{x}$ Correlation analysis was made after logarithmic transformation of CMV accumulation data ( $V, \mu \mathrm{g}$ of virion particles per $\mathrm{g}$ of fresh weight): $F=a+b \times$ $\ln V$ or CMV accumulation $(V)$ and transmission frequency $(F)$ data: $F=a \times$ $V^{\mathrm{b}}$, where $a$ and $b$ are regression parameters.

${ }^{y}$ Correlation coefficient.

${ }^{\mathrm{z}}$ Probability of the significance test for correlation.
}

cannot disregard the possibility that different relationships between transmission and CMV accumulation will hold in the presence or absence of CMV-satRNA. If this was the case, it would suggest a specific effect of CMV-satRNA on the transmissibility of its HV. Aphid transmissibility of CMV correlates with, or depends on, the amino acid sequence of the CP $(30,35,40)$, and sites determining transmission specificity by different species of aphids have also been reported (34). Some of these sites are thought to be exposed on the outer surface of the virus particles, whereas others are not, suggesting that their effect on transmissibility may be mediated by changes in the conformation or stability of the capsid structure (34). The presence of CMVsatRNA in CMV particles could modify the particle structure or dynamics, and hence, affect aphid transmissibility. Also, the distribution of CMV-satRNA with CMV genomic RNAs in CMV particles is not known (23). If satRNAs affect the encapsidation of CMV genomic RNAs or their distribution in a cell, they could indirectly affect the aphid transmissibility of the virus, because a successful transmission event requires the transfer of at least three CMV particles, each containing one of the three genomic RNAs. At present there are no data to test these hypotheses.

The results we present are important for understanding the dynamics and evolution of CMV populations in nature. CMVsatRNAs associate with many strains of CMV from different parts of the world (10). Nevertheless, in natural populations of CMV, the frequency of isolates supporting a satRNA is low $(1,14,20,43)$, a fact that could be explained if CMV-satRNAs were at a disadvantage for transmission relative to satRNA-free isolates. CMV-satRNAs are frequent in CMV populations in several reported epidemics of tomato necrosis caused by CMV isolates supporting satRNA variants necrogenic for tomato $(9,17,22,26)$. In most cases, both tomato necrosis and CMV-satRNAs disappeared within a few years. A detailed analysis of one such epidemic (1) suggests that CMV isolates supporting satRNA variants necrogenic for tomato would be at a disadvantage versus isolates supporting nonnecrogenic satRNA variants, but most analyzed fitness components favored necrogenic rather than nonnecrogenic satRNA variants (8). Under temperature conditions similar to those that favor a tomato necrosis epidemic, necrogenic satRNA variants caused a greater depression of CMV accumulation than nonnecrogenic variants (8). We did not observe a differential effect, but this could be attributed to temperature or other experimental conditions. For instance, transmission experiments and analyses of CMV accumulation were not all done at the same postinoculation times, because the development of symptoms varied. Physiological changes in tomato leaves associated with the necrotic process could also affect transmission, because aphids took longer to probe tomato leaves infected with Fny-CMV plus necrogenic satRNA variants than those infected with Fny-CMV alone or with nonnecrogenic variants. Thus, our results show that transmission-associated factors can be determinants in the evolution of natural populations of CMV-satRNA.

\section{ACKNOWLEDGMENTS}

F. Escriu was supported by a fellowship of Colaboración en Proyectos de Investigación Científica y Técnica de la Universidad Politécnica de Madrid, Spain. This work was supported, in part, by NATO grant 680 1155-0790 and grant BIO-96-1026-C02-01 (F. García-Arenal) and by the U.S. Department of Agriculture-NRI grant 1999-0251 (K. L. Perry).

\section{LITERATURE CITED}

1. Alonso-Prados, J. L., Aranda, M. A., Malpica, J. M., García-Arenal, F., and Fraile, A. 1998. Satellite RNA of cucumber mosaic cucumovirus spreads epidemically in natural populations of its helper virus. Phytopathology 88:520-524.

2. Aranda, M. A., Fraile, A., and García-Arenal, F. 1993. Genetic variability and evolution of the satellite RNA of cucumber mosaic virus during natural epidemics. J. Virol. 67:5896-5901. 
3. Badami, R. S. 1958. Changes in the transmissibility by aphids of a strain of cucumber mosaic virus. Ann. Appl. Biol. 46:554-562.

4. Banik, M. T., and Zitter, T. A. 1990. Determination of cucumber mosaic virus titer in muskmelon by enzyme-linked immunosorbent assay and correlation with aphid transmission. Plant Dis. 74:857-859.

5. Bernal, J. J., and García-Arenal, F. 1994. Analysis of the determinants of the satellite RNA of cucumber mosaic cucumovirus for high accumulation in squash. Virology 205:262-268.

6. Chen, B., and Francki, R. I. B. 1990. Cucumovirus transmission by the aphid Myzus persicae is determined solely by the viral coat protein. J. Gen. Virol. 71:939-944.

7. Copeland, R. 1998. Assaying levels of plant virus by ELISA. Pages 455460 in: Plant Virology Protocols: From Virus Isolation to Transgenic Resistance. G. D. Foster and S. C. Taylor, eds. Humana Press, Totowa, NJ.

8. Escriu, F., Fraile, A., and García-Arenal, F. 2000. Evolution of virulence in natural populations of the satellite RNA of Cucumber mosaic virus. Phytopathology 90:480-485.

9. Gallitelli, D., Franco, A. D., Vovlas, C., and Kaper, J. M. 1988. Infezioni miste del virus del mosaico del centriolo (CMV) e di potyvirus in colture ortive di Puglia e Basilicata. Inf. Fitopatol. 38:57-64.

10. García-Arenal, F., and Palukaitis, P. 1999. Structure and functional relationships of satellite RNAs of cucumber mosaic virus. Pages 37-63 in: Current Topics in Microbiology and Immunology. Vol. 239: Satellites and Defective Viral RNAs. P. K. Vogt and A. O. Jackson, eds. SpringerVerlag, Berlin.

11. Gera, A., Loebenstein, G., and Raccah, B. 1979. Protein coats of two strains of cucumber mosaic virus affect transmission by Aphis gossypii. Phytopathology 69:396-399.

12. Gibbs, A. J., and Gower, J. C. 1960. The use of a multiple-transfer method in plant virus transmission studies: Some statistical point arising in the analysis of results. Ann. Appl. Biol. 48:75-83.

13. Gonsalves, D., Provvidenti, R., and Edwards, M. C. 1982. Tomato white leaf: The relation of an apparent satellite RNA and cucumber mosaic virus. Phytopathology 72:1533-1538.

14. Grieco, F., Lanave, C., and Gallitelli, D. 1997. Evolutionary dynamics of cucumber mosaic virus satellite RNA during natural epidemics in Italy. Virology 229:166-174.

15. Jacquemond, M. 1982. L'ARN satellite du virus de la mosaïque du concombre. IV. Transmission expérimentale de la maladie nécrotique de la tomate par pucerons. Agronomie 2:641-646.

16. Jacquemond, M., and Leroux, J. P. 1982. L'ARN satellite du virus de la mosaïque du concombre. II. Étude de la relation virus-ARN satellite chez divers hôtes. Agronomie 2:55-62.

17. Jordá, C., Alfaro, A., Aranda, M. A., Moriones, E., and García-Arenal, F. 1992. Epidemic of cucumber mosaic virus plus satellite RNA in tomatoes in eastern Spain. Plant Dis. 76:363-366.

18. Kaper, J. M., and Tousignant, M. E. 1977. Cucumber mosaic virus-associated RNA5. I. Role of host plant and helper virus in determining the amount of associated RNAs with virions. Virology 80:186-195.

19. Kaper, J. M., Tousignant, M. E., and Lot, H. 1976. A low molecular weight replicating RNA associated with a divided genome plant virus: Defective or satellite RNA? Biochem. Biophys. Res. Commun. 72:1237-1243.

20. Kearney, C. M., Zitter, T. A., and Gonsalves, D. 1990. A field survey for serogroups and the satellite RNA of cucumber mosaic virus. Phytopathology 80:1238-1243.

21. Kennedy, J. S., Day, M. F., and Eastop, V. F. 1962. A conspectus of aphids as vectors of plant viruses. Commonw. Agric. Bur., London, U.K.

22. Kosaka, Y., Hanada, K., Fukunishi, T., and Tochibara, H. 1989. Cucumber mosaic virus isolates causing tomato necrotic disease in Kyoto Prefecture. Ann. Phytopathol. Soc. Jpn. 55:229-232.

23. Lot, H., and Kaper, J. M. 1976. Further studies on the RNA component among the nucleoproteins of cucumber mosaic virus. Virology 74:223-226.

24. Lot, H., Marrou, J., Quiot, J. B., and Esvan, C. 1972. Contribution à 1' étude du virus de la mosaïque du concombre (CMV). Méthode de purification rapide du virus. Ann. Phytopathol. 4:25-38.

25. Markham, P. G., Pinner, M. S., Raccah, B., and Hull, R. 1987. The acquisition of a caulimovirus by different aphid species: Comparisons with a potyvirus. Ann. Appl. Biol. 111:571-587.

26. Marrou, J., Duteil, M., Lot, H., and Clerjeau, H. 1973. La nécrose de la tomate: Une grave virose des tomates cultivées en plein champ. Pepinieres Hortic. Maraichere 137:37-41.

27. Moriones, E., Díaz, I., Rodríguez-Cerezo, E., Fraile, A., and García-Arenal, F. 1992. Differential interactions among strains of tomato aspermy virus and satellite RNAs of cucumber mosaic virus. Virology 186:475-480.

28. Mossop, D. W., and Francki, R. I. B. 1979. Comparative studies on two satellite RNAs of cucumber mosaic virus. Virology 95:395-404.

29. Normand, R. A., and Pirone, T. P. 1968. Differential transmission of strains of cucumber mosaic virus by aphids. Virology 36:538-544.

30. Owen, J., Shintaku, M., Aeschleman, P., Tahar, S. B., and Palukaitis, P. 1990. Nucleotide sequence and evolutionary relationships of cucumber mosaic virus (CMV) strains: CMV RNA 3. J. Gen. Virol. 71:2243-2249.

31. Palukaitis, P., and García-Arenal, F. 1999. Cucumber mosaic virus. In: Descriptions of Plant Viruses on CD-Rom. M. J. Adams, J. F. Antoniw, H. Baker, A. T. Jones, A. F. Murant, and D. J. Robinson, eds. Association for Applied Biologists, Warwick, U.K.

32. Palukaitis, P., Roossinck, M. J., Dietzgen, R. G., and Francki, R. I. B. 1992. Cucumber mosaic virus. Adv. Virus Res. 41:281-348.

33. Perry, K. L., and Francki, R. I. B. 1992. Insect-mediated transmission of mixed and reassorted cucumovirus genomic RNAs. J. Gen. Virol. 73:2105-2114

34. Perry, K. L., Zhang, L., and Palukaitis, P. 1998. Amino acid changes in the coat protein of cucumber mosaic virus differentially affect transmission by the aphids Myzus persicae and Aphis gossypii. Virology 242:204-210.

35. Perry, K. L., Zhang, L., Shintaku, H., and Palukaitis, P. 1994. Mapping determinants in cucumber mosaic virus for transmission by Aphis gossypii. Virology 205:591-595.

36. Pirone, T. P., and Blanc, S. 1996. Helper-dependent vector transmission of plant viruses. Annu. Rev. Phytopathol. 34:227-247.

37. Pirone, T. P., and Harris, K. F. 1977. Nonpersistent transmission of plant viruses by insects. Annu. Rev. Phytopathol. 15:55-73.

38. Pirone, T. P., and Megahed, E. 1966. Aphid transmissibility of some purified viruses and viral RNAs. Virology 30:630-637.

39. Pirone, T. P., and Thornbury, D. W. 1988. Quantity of virus required for aphid transmission of a potyvirus. Phytopathology 78:104-107.

40. Quemada, H., Kearney, C., Gonsalves, D., and Slightom, J. L. 1989. Nucleotide sequences of the coat protein genes and flanking regions of cucumber mosaic virus strain C and WL RNA3. J. Gen. Virol. 70:1065-1073.

41. Raccah, B., Gal-On, A., and Eastop, V. F. 1985. The role of flying aphid vectors in the transmission of cucumber mosaic virus and potato virus $Y$ to peppers in Israel. Ann. Appl. Biol. 106:451-460.

42. Rizzo, T. M., and Palukaitis, P. 1990. Construction of full-length cDNA clones of cucumber mosaic virus RNAs 1, 2, and 3: Generation of infectious RNA transcripts. Mol. Gen. Genet. 222:249-256.

43. Rodríguez-Alvarado, G., Kurath, G., and Dodds, J. A. 1995. Heterogeneity in pepper isolates of cucumber mosaic virus. Plant Dis. 79:450-455.

44. Sambrook, J., Fritsch, E. F., and Maniatis, T. 1989. Molecular Cloning: A Laboratory Manual. Cold Spring Harbor Laboratory, Cold Spring Harbor, NY.

45. Simons, J. N. 1958. Titers of three nonpersistent aphid-borne viruses affecting pepper in South Florida. Phytopathology 48:265-268.

46. Sokal, R. R., and Rohlf, F. J. 1981. Biometry. 2nd. ed. W. H. Freeman \& Co., New York.

47. Takanami, Y. 1981. A striking change in symptoms on cucumber mosaic virus-infected tobacco plants induced by a satellite RNA. Virology 109:120-126. 